\title{
簡易白色板作成法の検討およびその性能評価・校正
}

\section{Examination for Making Method of Reference Reflectance Panels and Validation}

\author{
山下 恵*・吉村 充則**・土田 \\ 聡 $* * *$ \\ 本多 嘉明****・梶原 康司*** \\ Megumi YAMASHITA, Mitsunori YOSHIMURA, Satoshi TUCHIDA, \\ Yoshiaki HONDA, Koji KAJIWARA
}

\begin{abstract}
This paper describes the making method of reference reflectance panels in the case of field observation. We discussed examinations of coating materials and painting methods in order to define the making method of reference panels. As for the quality of our produced reference panel, we carried out the bidirectional reflectance factor (BRF) measurement referred to the calibrated standard panel and the bidirectional reflectance distribution function (BRDF) calibration for the reference panel. The characteristic of our produced reference panel was confirmed to have almost same as the standard panel through our experiments.
\end{abstract}

\section{1.はじめに}

衛星リモートセンシングによる物理量推定や衛星セ ンサの代替校正などにおいては，そのパラメー夕取得 のために地表対象物の分光反射測定が必要となる。分 光反射測定には，反射係数算出の基準となる完全拡散 面に限りなく近い表面構造を持つ標準白色板が求めら れる。これまでも，標準白色板の作成やその評価に関 する研究 ${ }^{1,2)}$ はいくつかなされている。最近では, 野 外測定においても高い反射率を持ち方向依存性も少 ないと言われる市販の標準白色板 (Labsphere 社の Spectralon など）が利用されている例が見られる。し かしながらより確からしい精度を実現する測定は, 太陽条件が変化しない程度の短時間に, より多くの地

* 科学技術振興事業団 CREST, JST

** 京都大学東南アジア研究センター Center for Southeast Asian Studies, Kyoto University

*** 産業技術総合研究所 National Institute of Advanced Industrial Science and Technology

****千葉大学環境りモートセンシング研究センター Center for Environmental Remote Sensing, Chiba University

「写真測量とリモートセンシング」VOL. 40, NO. 2, 2001 $-26$
点での測定 ${ }^{3,4}$ が良とされており，その目的においては 複数枚の標準白色板が同時に必要となる。現実には， 市販されている標準白色板は，安価とは言えず，野外 測定における標準白色板の準備には一考を要する。

このような背景から本報告では，1）検定された標 準白色板の代用となりうる比較的安価で均質な性能を 有する白色板 (本報告では簡易白色板と呼ぶ) の作成, $2 ） そ の$ 性能評価, を目的とし, 簡易白色板作成法に 関する検討および試作を行い，その評価を行った。性 能については，検定された標準白色板を基準とした簡 易白色板の二方向性反射係数 (Bidirectional Reflectance Factor; BRF) を，暗室内の点光源下にお いて光源天頂角を変化させながら測定し，検定された 標準白色板の二方向性反射分布関数 (Bidirectional Reflectance Distribution Function: BRDF) から簡 易白色板の BRDF を求め校正し, その特性を比較し評 価した。

\section{2. 簡易白色板作成}

簡易白色板の作成フローを図 1 に示す。

作成法は, 先ず, 白色塗料材料・土台を検討し, 塗 料材料を配合する。次に, 塗料を 2 つの塗布方法によ 


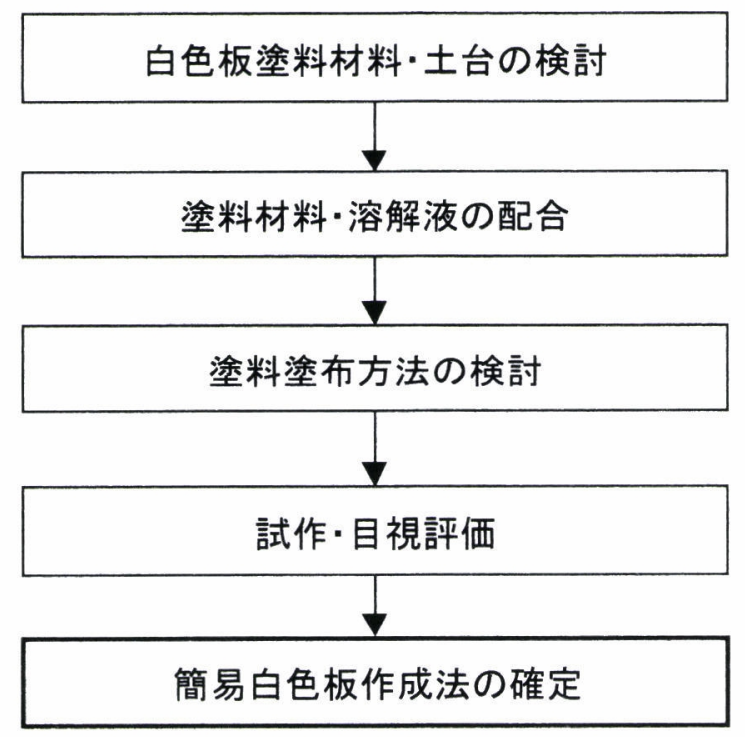

図 1 簡易白色板作成フローチャート

ク，白色板を試作する。試作した白色板に対し，目視 によって表面凹凸の有無などを確認し評価する。その 評価結果によって，塗料材料の量・配合比を再検討・ 配合し，試作を繰り返す。最終的に，最も良質である と確認された白色板を選び，その場合の土台，塗料材 料の量・配合比, 塗布方法の組み合わせを作成法とし て確定する。

以下, フローの順に, 各項目の詳細を説明する。

\section{1 白色塗料の材料・土台の検討}

白色塗料の材料には, 比較的広い波長域において高 い反射率をもつ，1）酸化マグネシウム $(\mathrm{MgO}) ， 2$ ) 高純度の硫酸バリウム $\left.\left(\mathrm{BaSO}_{4}\right) ， 3\right)$ 塩化ナトリウム $(\mathrm{NaCl}), 4)$ ポリテトラフルオロエチレン (PTFE; Polytetrafluoroethylene： ‘テフロン® で知られる。 Labsphere 社の ‘Spectralon’ はこれがべース材料で ある）などが適していると言われる5,6)。しかし，1） $\mathrm{MgO}$ は，時間経過にともう反射率変化や破損しやす いといった点で, 野外での使用には不向きである。3） $\mathrm{NaCl}$ については, 結晶粒子も大きく, また溶解方法や 塗布方法を考之ると“白色板’として適していない。4) PTEF は, 金属板で圧縮し用いられているが6), 加工は 容易でない。これらの理由から，入手しやすく比較的 加工しやすい点で，2）高純度の硫酸バリウム（ここ では Kodak white reflectance standard No.6091を 使用，以下，Kodak $\mathrm{BaSO}_{4}$ と記す) 塗料材料として
選択した。

Kodak $\mathrm{BaSO}_{4}$ の溶解液には, 合成洗濯のりの原料に 使われる接着成分のポリビニールアルコール（ここで は，不純物を含まない固形（以下 PVA と記す：99\% hydrolyzed)のものを使用と, PVA を溶解するための 蒸留水, 塗料の乾燥を早める溶剂としてエチルアル コールの 3 種類を準備した。

白色板の土台は，熱や湿気に強い厚みを持った金属 板やガラス板などが考えられる。加工や取扱などを考 慮すると, ガラス板は適していない。ここでは, 市販 品の厚さ $3 \mathrm{~mm}$ のアルミ板と厚さ $4 \mathrm{~mm}$ のタイル（裏 側を付着面に使う）の 2 種類を用意した。また，塗料 を付着しやすくするために，画者共に目の粗いヤスり で表面を研磨した。

\section{2 塗料材料・溶解液の配合}

準備した塗料材料と溶解液の配合手順について説明 する。

1) 接着成分であるPVAと蒸留水をビーカーに入 れ, 四 2 に示すようにホットスターラーを約 $60-80^{\circ} \mathrm{C}$ に温度設定し，3，4 時間程度加熱擋找を続け, PVA 溶液を作成する。このとき, 水分の蒸発を防ぐため, ビーカーにラップをかけ中心部を凹ましておく。完 全に溶けたらろ過する。

2) Kodak $\mathrm{BaSO}_{4}$ は微粒子で塊になっていることが あるため，混ざりやすいように細かく砕き，それと エチルアルコールを少量ずつ大きめのビーカーに加 え，ガラス棒もしくはさじで混ぜ合わせる。

3) 2)の Kodak $\mathrm{BaSO}_{4}$ とエチルアルコールを混ぜ

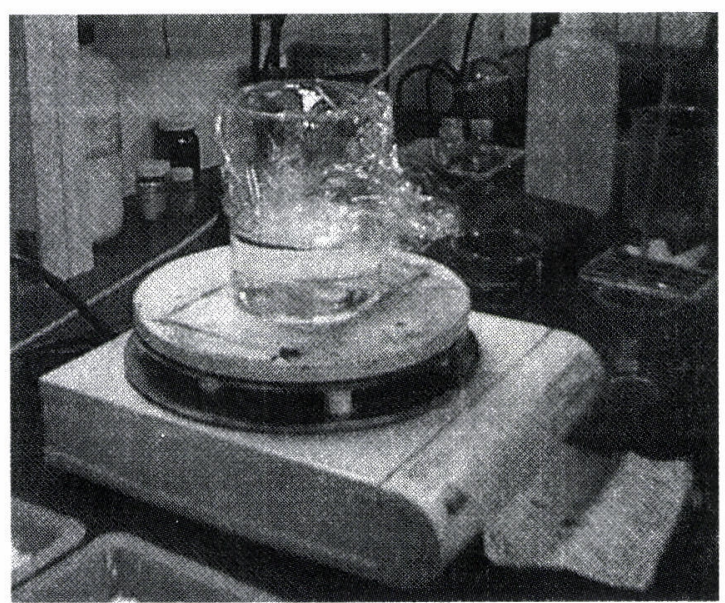

図 2 ホットスターラーと PVA 溶液作成風景 
たものに，1)で作成したPVA 溶液を加え，1）と同 様にホットスターラーの温度を最初は $100^{\circ} \mathrm{C}$, 少しず つ下げて50-60 $\mathrm{C} に$ 設定し, 加熱しながらなめらかに なるまで摚拌を続ける。このときも，ビーカーには ラップをして水分とアルコールの蒸発を防ぐ。

\section{3 塗料塗布方法}

塗布は，以下に記す 2 つの方法で行った。

方法 1.エアコンプレッサとスプレーガンを用い，作 成した白色塗料を土台（アルミ板，タイル） 均一に吹き付ける。（以下，スプレ一式と記す） 方法 2 . 白色塗料を, 土台 (アルミ板, 夕イル) に直 接へラなどで塗り付け，バットなどの容器に入 れてふたをし，充分に乾燥固化させる。その後， 耐水性ヤスリ（\#240，300，400，600，800）を 平らなアルミ板 (白色板土台と同程度のサイズ) に卷き付けて，粗いものから細かいものに順に 変えて，表面の凹凸を見ながら削り，均質にし ていく。(以下，乾燥固化研磨式と記す）

\section{4 試作・目視評価}

白色板の試作は， 2 種類の土台 (アルミ板，タイル)

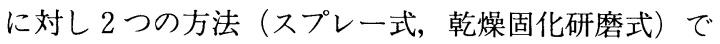
塗布して行った。試作した白色板は，1)アルミ板・ス プレー式，2)タイル・スプレー式，3)アルミ板・乾 燥固化研磨式，4) 夕イル・乾燥固化研磨式の合計 4 種 類である。それぞれに対する目視評価を，表面凹凸の 有無, 塗料の塗布斑の有無, 塗料粘着性や乾燥具合か ら行った。

\section{5 簡易白色板作成法の確定}

試作した白色板 4 種類の目視評価結果について以下 にまとめる。

1) アルミ板・スプレ一式，および2) タイル板・ス プレー式については, 塗料の粘着性はアルミ板とタイ
ル共に変わらなかったが，土台面以外にも吹き付ける ために塗料が無䭾になったり, $\mathrm{BaSO}_{4}$ の厚みを作るの に時間を要した。吹き付け中に，ゴミが一緒に土台へ 付着したり，射出しやすくするために蒸留水・エチル アルコールを途中で加えることもあった。また，スプ レ一中に表面に凹凸や斑ができると，修正が困難で あった。スプレー式による塗布は，労力・費用ともに， あまり効率的ではなかった。3)アルミ板・乾燥固化研 磨式，4）タイル・乾燥固化研磨式による試作では，特 別な機材は必要とせず全作業が室内で可能だった。塗 料も無駄なく使うことができた。3)によるアルミ板の 土台は，4）による夕イルに比べて, 塗料粘着性が低く, 乾燥中にはがれ落ちたりすることもあった。乾燥固化 は，自然で行い（ドライヤーを使用したところ，ひび 割れたり空気中のホコリが付着した), 湿度の高い時期 でも 3 日間程度だった。乾燥固化研磨式では，実作業 時間はかからず，また特別な技術も必要としなかった。

以上のことから，4)の土台には市販の夕イル裏面, 塗布方法は乾燥固化研磨式の組み合わせが, 最も均質 な簡易白色板が作成できることが確認できた。した がって, 表 1 に示寸塗料材料・溶解液の量・配合比で, タイル裏面を土台とし，乾燥固化研磨式による塗布方 法を，簡易白色板作成法として，確定した。なお，表 1 に示すそれぞれの量·配合比で，10cm 四方の簡易白 色板が 6 枚作成でき，1枚当たりの材料費は，2500円 程度であった。

\section{3 . 簡易白色板の性能評価}

簡易白色板の性能は，簡易白色板自身の持つ二方向 性反射分布関数（以下，BRDF と記す）特性を，検定 された標準白色板 (Labsphere 社製 Spectralon) と, 比較用に同 Labsphere 社のロットの違う Spectralon (以降, 比較用白色板と記す)の BRDF 特性と比較する ことによって評価することにした。なお，この検定さ

表 $110 \mathrm{~cm}$ 四方の白色板 6 枚分の塗料材料・溶解液の量および配合比

\begin{tabular}{|l|c|c|}
\hline \multicolumn{1}{|c|}{ 塗料材料・溶解液 } & 重量 $(\mathrm{g})$ & 配合比 $(\%)$ \\
\hline Kodak White reflectance standard $\left(\mathrm{BaSO}_{4}\right)$ & 90 & 42.86 \\
\hline $\begin{array}{l}\text { Polyvinyl alcohol (PVA) 99-100\% hydoloyed } \\
\text { /蒸留水 (PVA2.5\%溶液) }\end{array}$ & 70 & 33.33 \\
\hline エチルアルコール & 50 & 23.81 \\
\hline
\end{tabular}

*PVA2.5\%溶液は，多めに作成しておくと便利 
れた標準白色板は, センサ角を $0^{\circ}$, 光源天頂角を 10-850 5 間隔で反射係数絶対值を測定し, BRDF が 求められたものである。

性能評価のために, 先ず, 室内計測設備のもとで, 検定された標準白色板を基準とし, センサ角を 0 に固 定し, 光源天頂角 $\theta$ を変化させながら, 被測定対象と する簡易白色板と比較用白色板の分光反射強度を測定 し，標準白色板に対寸る簡易白色板と比較用白色板の 二方向性反射係数（以下， BRF と記す）を算出した。 次に，算出した BRF を用い，検定された標準白色板の BRDF から，簡易白色板と比較用白色板の BRDFを 求めた。

\subsection{BRF 測定}

BRF 測定は，標準電球 (ウシオ電機社製，分光放射 照度標準電球）が備わった簡易小型暗室ケース内で実 施した。分光放射計には，Field Spec FR (Analytical Spectral Devices 社)を用い, センサ視野角は $8^{\circ}$ とし, 波長範囲を可視近赤外域 $(400-1000 \mathrm{~nm})$ とした。

測定は，図 3 に示す要領で行った。光源 (Source) である標準電球は固定し Sensor と Panel のなす角度 が $90^{\circ}$ になるように, 光源天頂角 $\theta$ が $\theta=15^{\circ}$ (図中灰色 の Sensor, Panel) から $75^{\circ}$ (図中白色の Sensor, Panel) までを 5 間隔の角度で Panel と Sensor を移動する。

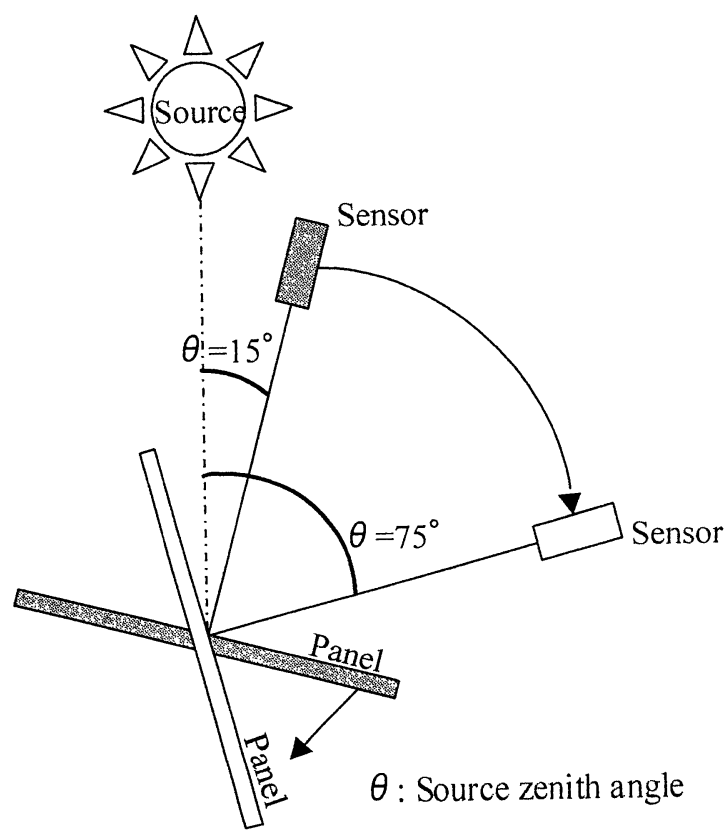

図 3 光源天頂角変化による BRF 測定模式図
光源天頂角 $\theta$ 毎に，標準白色板，簡易白色板，比較用 白色板，の順に置き換えながらそれぞれの分光反射強 度を測定する。標準白色板に対する被測定対象白色板 の反射係数は，式(1)によって求められる。

$R^{\prime} \operatorname{smp}(0 / \theta)=D N s m p(0 / \theta) / D N s t d(0 / \theta)$

ここで,

0 ：センサ角（nadir）

$\theta$ : 光源天頂角 $(15,20,25,30,35,40,45,50$, $\left.55,60,65,70,75^{\circ}\right)$

$R^{\prime} s m p(0 / \theta) \quad: \theta$ のときの標準白色板に対する被測 定対象白色板の反射係数

$D N s m p(0 / \theta): \theta$ のとき被測定対象白色板の放射 計デジタルカウント值

$\operatorname{DNstd}(0 / \theta) \quad: \theta$ のときの標準白色板の放射計デジ タルカウント值

式(1)から, 天頂角 $\theta$ 毎の標準白色板に対する簡易白 色板および比較用白色板の BRFをそれぞれ算出し た。

\subsection{BRDF 校正}

一般に BRDF は，ある光源方向 $(\phi, \theta)$ から照射す る放射照度 $d E(\phi, \theta)$ に対する測定対象物からセンサ 方向 $\left(\phi^{\prime}, \theta^{\prime}\right)$ への放射輝度 $d L\left(\phi^{\prime}, \theta^{\prime}\right)$ の比で表され， 式(2)となる。

$F\left(\phi, \theta ; \phi^{\prime}, \theta^{\prime}\right)=d L(\phi, \theta) / d E\left(\phi^{\prime}, \theta^{\prime}\right)$

ここで,

$F\left(\phi, \theta ; \phi^{\prime}, \theta^{\prime}\right):$ 対象物の BEDF

$\phi, \theta$ : 光源の方位, 天頂角

$\phi^{\prime}, \theta^{\prime}$ : センサの方位, 角度

測定において基準に用いた標準白色板の BRDF は, アリゾナ大学の専用測定施設において，センサ角を 0 。 に固定し，天頂角 $10^{\circ}$ から $85^{\circ}$ までの $5^{\circ}$ 間隔毎に，450$2400 \mathrm{~nm}$ の波長範囲で18波長带の反射係数絶対值が值 付けされている。

したがって，センサ角を $0^{\circ}$ ，光源方位 $\phi$ を固定し， 天頂角 $\theta$ を変化させて測定した場合, センサ方向 $\left(\phi^{\prime}\right.$, $\left.\theta^{\prime}\right)$ および光源方向 $\phi$ は定数となる。被測定対象白色 板の BRDF は，值付けられた標準白色板の BRDF を 用いれば，式(3)から求められる。

$F \operatorname{smp}(\theta)=R^{\prime} \operatorname{smp}(0 / \theta) \times F_{s t d}(\theta)$

ここで,

$F s m p(\theta): \theta$ を変数とする被测定対象白色板の BRDF 
$F s t d(\theta)$ : $\theta$ を変数とする標準白色板の BRDF（既 知)

BRF 測定は400-1000nm を対象としたので，標準白 色板の值付けられた18波長带から，可視近赤外域 455 , 502，554，647，699，757，860，948nm を中心する $\pm 5 \mathrm{~nm}$ の 8 波長带それぞれについて，天頂角 $\theta$ 変化 による簡易白色板抒よび比較用白色板の BRDF を式 (3)より求めた。

\subsection{BRDF 特性比較}

図 4 に，式(3)で算出した簡易白色板および比較用白 色板の可視近赤外域の 8 波長带における天頂角 $\theta$ 変

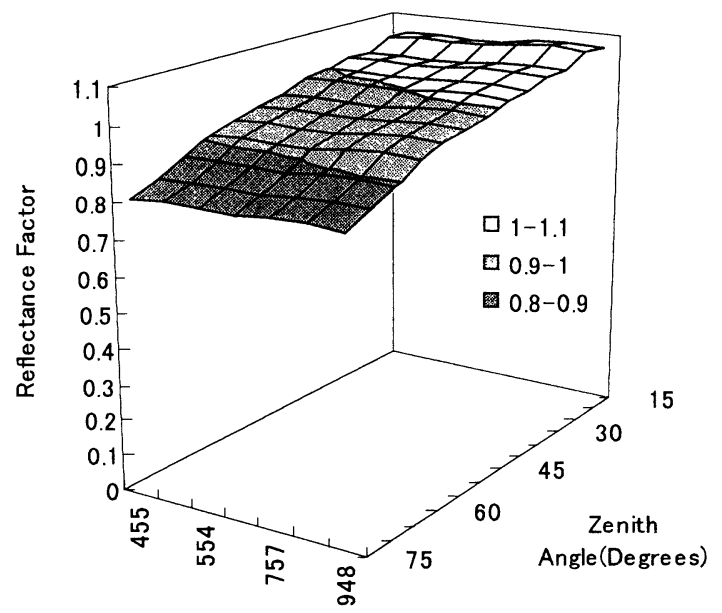

Wavelength(nm)

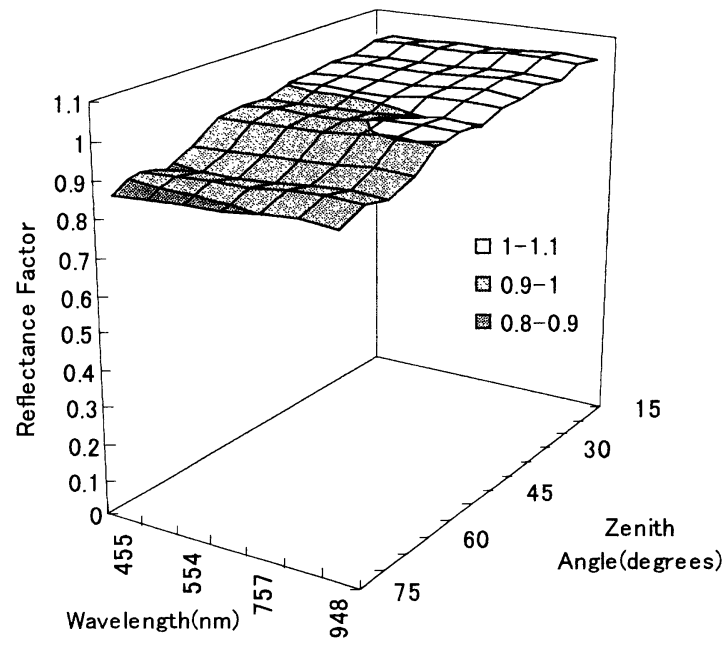

図 4 比較用白色板（上）と簡易白色板（下）の可視近赤外 域における BRDF
化の BRDF を示す。両者が完全拡散面と仮定すると， $\theta$ 変化による波長別の反射係数はすべて 1 で一定し, グラフは平面となる。比較用白色板に用いた, 反射率 が高く方向依存の少ないと言われる Spectralonにも, 固有の BRDF 特性があることがわかる。また，簡易白 色板 BRDF の方向依存抄よび波長依存性は, 少ないこ とがわかる。

困 5 a, b, c は, 可視域 $554 \mathrm{~nm}, 699 \mathrm{~nm}$ ，近赤外域 $860 \mathrm{~nm}$ の 3 波長带における天頂角 $\theta$ 変化の標準白色 板, 簡易白色板および比較用白色板の BRDF である。 四中のポイント $\Delta ， \boldsymbol{O} ＼mathrm{~ 口 は ， そ れ そ ゙ れ 標 準 白 色 板 ， ~}$
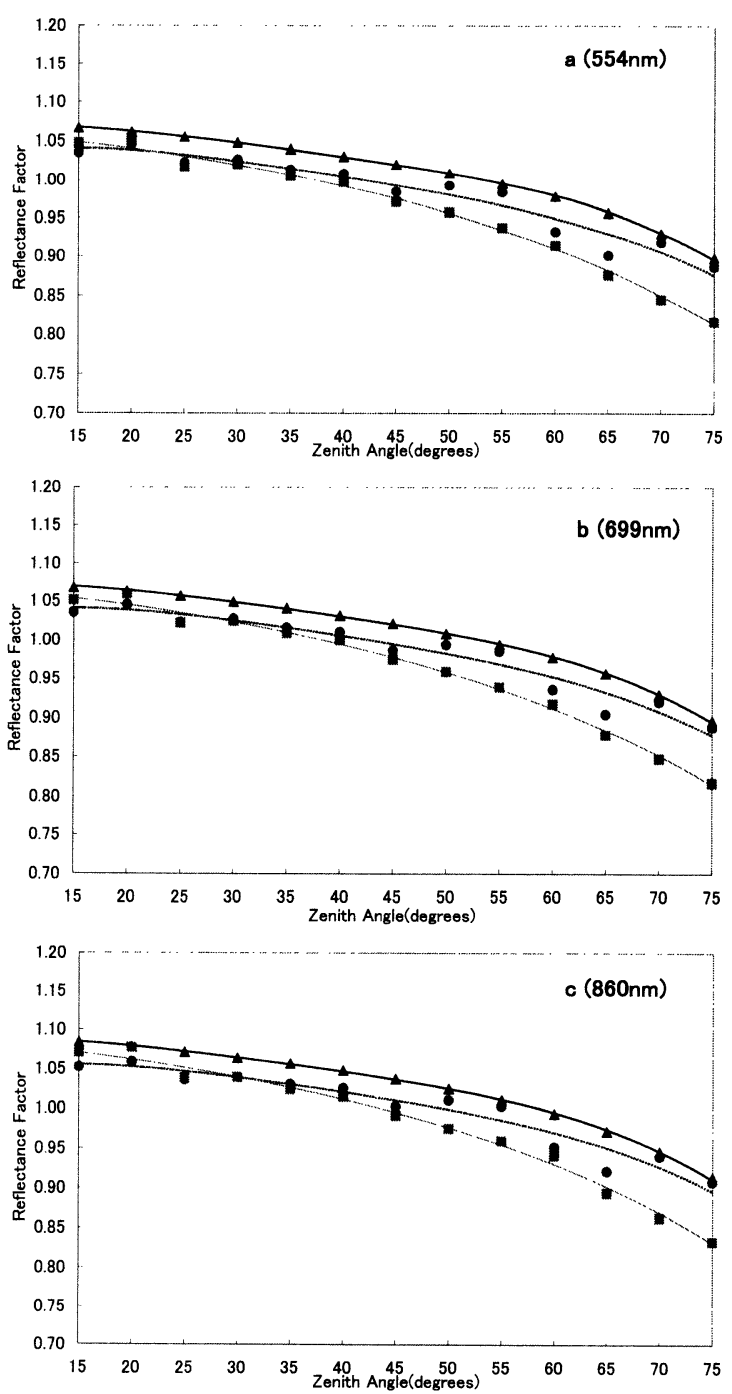

図 $5554 \mathrm{~nm}, 699 \mathrm{~nm}, 860 \mathrm{~nm}$ における天頂角変化の標準白 色板 $(\boldsymbol{\Delta})$ ，簡易白色板 $(\boldsymbol{O})$ ，比較用白色板 $(\square) の$ 反射係数絶対值と 4 次近似した BRDF (上から順に, a ; 554nm, b ; 699nm, c ; 860nm) 
簡易白色板, 比較用白色板の反射係数絶対値を示し, グラフ上のラインは，それぞれの反射係数絶対值を 4

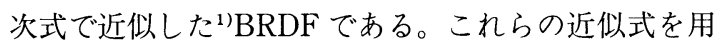
いれば, 任意の天頂角 $\theta$ で測定した対象物の反射係数 の絶対值を求めることができる。また，簡易白色板の BRDF 曲線は, 標準白色板と比較用白色板のそれとを 比較すると, グラフ a, b , c ともによく似た曲線（上 に凸）をし，また両者の間に位置している。つまり， 検定された標準白色板と，そのロットの異なる比較用 白色板にも両者の差が見られるが, 簡易白色板はその 差の間に位置し，充分な性能を有していると言える。

なお, Jackson(1992) ${ }^{1}$ らが行った, Spectralon と彼 等が作成した $\mathrm{BaSO}_{4}$ 白色板に対する同様の測定結果 によると，4 次式で近似した $\mathrm{BaSO}_{4}$ 白色板の $\mathrm{BRDF}$ は，Spectralonのそれと異なった曲線（下に凸）また は直線に近い曲線を示しばらつきも見られ, 反射係数 も全体的に低かった。それらの要因は, $\mathrm{BaSO}_{4}$ の塗布 方法に依存すると彼等は指摘している。

これらの結果, 乾燥固化研磨式によって筆者らが作 成した簡易白色板の性能は, 検定された標準白色板と その比較用白色板と同等の BRDF 特性をもち, 野外で の分光反射測定に ‘標準白色板”に用いるものとして, 評価できる。

\section{4.まとめ}

本報告では, 比較的安価で検定された標準白色板と 同等の性能を有する簡易白色板作成法を検討し，その 評価と BRDF 校正を行った。以下に, 作成法および性 能評価をまとめる。

・白色板土台には, 加工に手間のかからない市販の夕 イルなどを用いるとよい。

・硫酸バリウムの塗料塗布法は, スプレーによる塗布 よりも，土台に塗り付けて乾燥固化させ，耐水性ヤ スリで研磨するほうが，効率的に充分な厚みを持っ た白色板が作成できる。

・提案する作成法によれば, 白色板表面が污れたり傷 がついても，その上から新しい塗料を塗ることに よって再利用が可能である。

・簡易白色板は，天頂角変化による反射係数の大きな 低下やばらつきは少なく，一般に分光放射測定にお いて標準とされている Spectralonの BRDF と同等 の特性をもつ。
以上のことから，作成した簡易白色板は，筆者らの 想定する野外分光放射測定において標準白色板として 充分適用できるものと結論できる。

最後に，太陽天頂角変化を考慮した野外分光放射測 定を行う際には, 白色板の BRDF 測定を同時に行うこ とが望ましい。その測定方法に関しては, 参考文献 6), 7 )，8）を参照されたい。

なお本報告は，科学技術振興事業団(JST) 戦略的基 礎研究推進事業部 (CREST)「地球変動のメカニズム」 研究領域にける『熱帯林の林冠における生態圈一気圈 相互作用のメカニズムの解明』で得られた成果の一部 である。

謝辞

簡易白色板作成を進めるにあたり，白色板の塗料材 料の検討においては, 科学技術振興事業団の山本浩万 氏，千葉大環境りモートセンシング研究センターの近 田朝子氏に，多大な協力と助言を戴いた。また，白色 塗料の塗布方法については，木村凱昭氏および，秀光 電機株式会社須佐泰隆氏に，貴重なご意見を戴いた。 ここに記して感謝を表す。

（受付日2000.11.6, 受理日2001.3.14）

\section{参考文献}

1) Ray D. Jackson., et al. : Bidirectional Calibration Results for 11 Spectralon and $16 \mathrm{BaSO}_{4}$ Reference Reflectance Panels, Remote Sensing Env., Vol. 40, pp. 231-239, 1992.

2 ) 古賀, 石山, 梶原, 本多：標準白色板の反射特性 評価, 平成 8 年度日本写真測量学会年次学術講演会 論文集，pp. 63-64， 1996.

3 ) 梶原, 本多, 木村, 須佐 : 野外用分光反射率観測 システムに関する研究, 平成 7 年度日本写真測量学 会秋季学術講演会論文集, pp. 237-240, 1995.

4) 吉村, 山下, 野村, 中静: 熱帯林・林冠観測クレー ンをプラットフォームとする三次元・分光計測シス テムの開発とその運用, 平成12年度日本写真測量学 会秋季学術講演会論文集, pp. 127-130, 2000.

5 ) 江森康文, 安田嘉純：フィールドにおける分光反 射測定, キャノンイメージ編 REMOTE SENSING, pp. 297-316, 1969.

6 ) Ray D. Jackson, M. Susan Moran, et al. : Field Calibration of Reference Reflectance Panels, 
Remote Sensing Env., Vol. 22, pp. 145-158, 1987.

7 ) Elizabeth A. Walter-Shea, Ray D. Jackson, et al. : An Improved Goniometer System for Calibrating Field Reference-Reflectance Panels, Remote Sensing Env., Vol. 43, pp. 131-138, 1993.
8 ）土田, 佐藤, 岡田：空間不均一性を考慮した地表 面 BRDF 測定システムースペクトロラジオメー タ・デジタルカメラの併用一，日本リモートセンシ ング学会誌, Vol. 19, No.4, pp. 49-59, 1999.

\section{コンピュータプログラム販売の御案内}

日本写真測量学会では次のプログラムの販売を行っています。御希望の方は事務局（Tel 03-3984-7040, Fax 03-3984-7402）まで御問合せ下さい。

（賛助会員価額，消費税別）

1. バンドル法空中三角測量（汎用計算機用）

120 万円

2. 同上 (パソコン用)

60 万円

3.PG MAN（一般カメラによる三次元座標計測）

50 万円

4. BIRD MAN （PG MAN にステレオ視機能を付加）

60 万円

5. SPOT DTM（SPOT ステレオ画像からの DTM 自動作成）

150 万円 